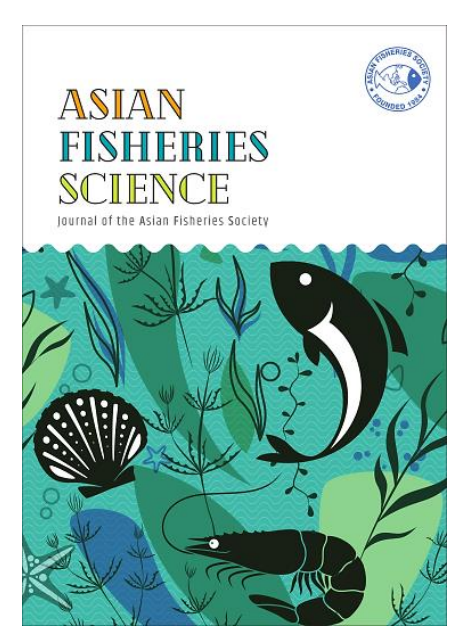

() Asian Fisheries Society

ISSN: 0116-6514

E-ISSN: 2073-3720

https://doi.org/10.33997/j.afs.2020.33.S1.007

\section{Contact-Zoonotic Bacteria of Warmwater Ornamental and Cultured Fish}

\author{
OLGA HAENEN ${ }^{1, *}$, IDDYA KARUNASAGAR ${ }^{2}$, AMEDEO MANFRIN ${ }^{3}$, SNJEZANA ZRNCIC ${ }^{4}$, \\ CELIA LAVILLA-PITOGO ${ }^{5}$, MARK LAWRENCE ${ }^{6}$, LARRY HANSON ${ }^{6}$, ROHANA SUBASINGHE ${ }^{7}$, \\ MELBA G. BONDAD-REANTASO ${ }^{\circ}$, INDRANI KARUNASAGAR ${ }^{2}$ \\ 'Wageningen Bioveterinary Research, WBVR, P.O. Box 65, 8200 AB Lelystad, the Netherlands \\ ${ }^{2}$ Nitte University, Medical Enclave, Deralakatte, Mangalore 57501805, Karnataka, India \\ ${ }^{3}$ Istituto Zooprofilattico Sperimentale delle Venezie, Viale dell'Università 1035020 Legnaro (PD), Italy \\ ${ }^{4}$ Croatian Veterinary Institute, Savska cesta 143, 10000 Zagreb, Croatia \\ ${ }^{5}$ Tigbauan 5021, lloilo, Philippines \\ ${ }^{6}$ Mississippi State University, Starkville, Mississippi, United States \\ ${ }^{7}$ FUTUREFISH, 16I ICONIC, 110 Parliament Road, Rajagiriya, Sri Lanka \\ ${ }^{8}$ Fisheries Division, Food and Agriculture Organization of the United Nations (FAO), Rome, Italy \\ *E-mail: olga.haenen@wur.nl
}

\title{
Abstract
}

In this small review, the most important contact-zoonotic bacteria and the diseases they cause in fish and humans are described. Especially, warmwater ornamental and fish culture professionals, owners, and processors are at risk in acquiring infections by Vibrio vulnificus, Photobacterium damselae subsp. damselae, Aeromonas hydrophila, Edwardsiella tarda, Mycobacterium marinum, Streptococcus iniae, or Streptococcus agalactiae, transmitted from their fish and fish water, in freshwater to marine environments. The chance of acquiring such a zoonosis is low, unless humans are immuno-compromised, and in case their skin is injured. These zoonoses are under reported, as in most countries they are non-notifiable. Strict hygiene for humans having direct contact with these fish in various fish holding and rearing facilities, and regular screening and health checks of imported warmwater ornamental fish at airports are recommended to avoid zoonosis and spread of potentially zoonotic, and often multiresistant bacteria.

Keywords: fish health, zoonosis, disease, antibiotics, antimicrobial resistance

\section{Introduction}

At a global scale, numerous warmwater fish species may be cultured as food or as ornamental fish in tropical countries, cultured indoors in warm water as food fish (FAO, 2018), or kept in warmwater aquaria as tropical ornamental fish; there are more than 800 ornamental species, mostly farmed in Asia (OFI, 2018). Warmwater fish may carry or be infected with zoonotic bacteria which may be harmful to humans via contact, i.e. potentially contact zoonotic (Lehane and Rawlin, 2000; Haenen et al., 2013). Moreover, as warmwater ornamental fish are often treated with various antibiotics before transport, and as multiresistant bacteria are proven to be present (Chanda et al., 2011; Weir et al., 2011), this implies a risk of transmission of multiresistant bacteria to humans.

Risks apply to fish handlers in the country of origin as well as in the importing country, in the transfer port in case water of the fish bags is refreshed, and in importing countries where live warmwater fish are unpacked to enter the chain of ornamental fish trade as pets. Groups at risk are all individuals in direct skin contact with live fish, residues, and fish water. This includes professionals in all segments of the ornamental fish business (aquaculture and fisheries), inspections and, to a lesser extent, persons keeping an aquarium at home and recreational fish anglers. Most countries, including the European Union (EU), don't have legislation on prevention for these potential human health risks in place at international border inspections posts.

The principal pathogens causing contact zoonoses from either handling fish through spine puncture or open wounds are Vibrio vulnificus, Photobacterium damselae subsp. damselae, Aeromonas hydrophila, Edwardsiella tarda, Mycobacterium marinum, Streptococcus iniae, and Streptococcus agalactiae (Dryden et al., 1989; Lawler, 1994; Weinstein et al., 1997; Lehane and Rawlin, 2000; Chotmongkol et al., 2004; Oliver, 2005; Haenen et al., 2013). In exceptional cases, Vibrio parahaemolyticus may also cause contact 
Most contact-zoonotic bacteria grow well at water temperatures above $25^{\circ} \mathrm{C}$, and these bacteria may, therefore, pose a risk in subtropical and tropical regions or indoor warmwater aquaculture systems. These pathogens are all indigenous to the aquatic environment and have also been associated with disease outbreaks in food fish. Although most fishassociated wound infections are self-limiting, more serious cases are mostly associated with an underlying immune deficiency or incompetence in the patient, infection with highly virulent strains, contact with a large inoculum, depth of penetration of the skin, or a combination of these factors. Patients may develop mild to severe infections that, in exceptional cases, may prove lethal, as in the case of $V$. vulnificus (Haenen et al., 2013).

\section{Fish Diseases Caused by Common Zoonotic Bacteria}

Vibrio vulnificus may cause haemorrhagic disease in eels. Fish may show redness of the flanks of the body and tail (Austin and Austin, 1999). In advanced cases, pathological changes may be observed in the gills, heart, liver, spleen, and gastrointestinal tract (Miyazaki et al., 1977). Clinical signs in European eels (Anguilla anguilla (Linnaeus, 1758)) differed between the non-zoonotic ST 140 strain (Fig. 1), which showed open ulcers, and the zoonotic strain ST 112 (Fig. 2), which showed muscle boils that burst open (Haenen et al., 2014). In diseased tilapia, haemorrhages around the fin bases, exhaustion in swimming behaviour, and stiffness of muscles were observed as a chronic condition and resulted in a gradual death of 10 to $20 \%$ of the pond fish (Sakata and Hattori, 1988). Vibrio vulnificus is found in warm coastal and estuarine environments and can be associated with even healthy aquatic animals. Infection by $V$. vulnificus may happen due to contact with seawater or estuarine water.

Photobacterium damselae spp. damselae is a normal inhabitant of the marine environment (Hawke, 2014), and causes a chronic bacterial infection characterised by skin ulceration that may progress to haemorrhagic septicaemia. This occurs in a wide variety of marine fish including Japanese amberjack (Seriola quinqueradiata Temmnck and Schlegel, 1845), gilthead seabream (Sparus aurata Linnaeus, 1758), European seabass (Dicentrarchus labrax (Linnaeus, 1758)), Senegalese sole (Solea senegalensis Kaup, 1858) common sole (Solea solea (Linnaeus, 1758)), striped bass (Morone saxatilis (Walbaum, 1792)), hybrid striped bass (M. saxatilis $\times$ M. chrysops (Rafinesque, 1820)), and white perch (Morone americana (Gmelin, 1789))(Romalde, 2002; Rivas et al., 2013). Fish affected by systemic infection show fatty liver with petechiae, abdominal swelling caused by splenomegaly, and ascites (Labella et al., 2011).

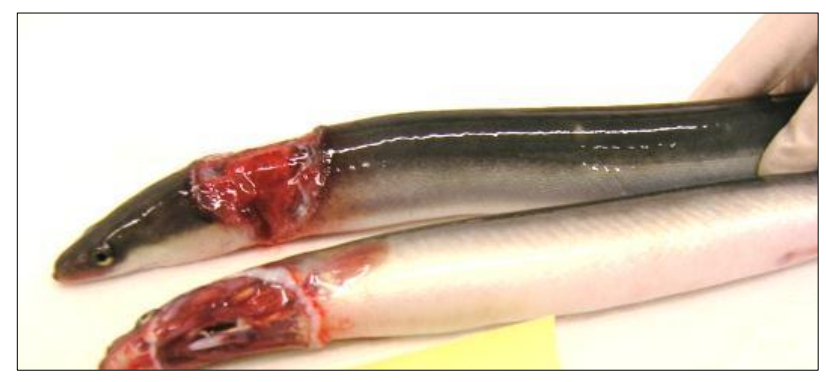

Fig. 1. Vibrio vulnificus infection in eel by the non-zoonotic ST 140 strain (Haenen et al., 2014).

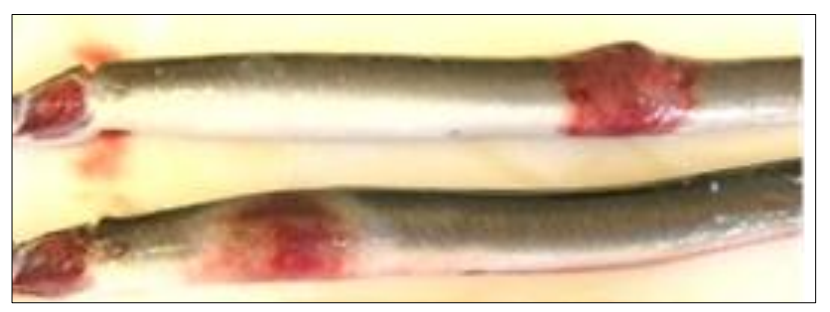

Fig. 2. Vibrio vulnificus infection in eel by the zoonotic ST 112 strain (Haenen et al., 2014).

Aeromonas hydrophila is considered ubiquitous in fresh and brackish water and is a facultative pathogen of various cold- and warm-blooded animals. It may cause motile aeromonad septicaemia, haemorrhagic septicaemia, motile aeromonad infection, red pest, red sore ulcerative disease, and furunculosis, especially in intensively cultured warmwater fish such as Indian major carps, catfish, cyprinids, goldfish, etc. (Austin and Adams, 1996; Camus et al., 1998; Austin and Austin, 2007). A highly virulent pathotype of $A$. hydrophila (vAh) is emerging in the United States of America, causing high losses in the channel catfish industry (Hossain et al., 2014).

Edwardsiella tarda is considered one of the most important bacterial pathogens in aquaculture worldwide (Kodama et al., 1987; Castro et al., 2006; Xu and Zhang, 2014). It has been reported as a causative agent of edwardsiellosis from over 20 fish species across five continents (Plumb, 1999; Mohanty and Sahoo, 2007). It has also been isolated from reptiles, birds, and mammals (Sharma et al., 1974; Tan and Lim, 1977; Leotta et al., 2009; Wang et al., 2012). Its major economic impact is in disease outbreaks in both freshwater and brackish water cultured fish. The disease includes small cutaneous ulcerations on the sides and caudal peduncle that can progress into deep abscesses in the musculature with gas (Meyer and Bullock, 1973).

Streptococcus iniae may cause haemorrhagic disease in various freshwater and marine warmwater fish species, like channel catfish (Ictalurus punctatus (Rafinesque, 1818)), Nile tilapia (Oreochromis niloticus (Linnaeus, 1758)), barramundi (Lates calcarifer (Bloch, 1790)), European seabass, gilthead seabream, bastard 
halibut (Paralichthys olivaceus (Temminck and Schlegel, 1846)), white-spotted spinefoot (Siganus canaliculatus (Park, 1797)) and red porgy (Pagrus pagrus Linnaeus, 1758)), but also in rainbow trout (Oncorhynchus mykiss (Walbaum, 1792)) and some ornamental fish (Kitao et al., 1981; Kusuda, 1992; Perera et al., 1994: Eldar et al., 1995). Haemorrhagic meningoencephalitis often accompanied by blindness is typical for this disease. At necropsy, pale and/or haemorrhagic liver and kidney, swollen spleen, and occasionally ascites are seen (Soltani et al., 2005; Salati, 2011).

Steptococcus agalactiae is an important fish pathogen and causes warmwater streptococcosis. It has been isolated from humans, various warmblooded animals, and various freshwater, brackish, and marine farmed, wild and ornamental fish species (Evans et al., 2008; Amal and Zamri-Saad, 2011; Bowater et al., 2012; Delannoy et al., 2013). The disease affects fish species like Nile tilapia, hybrid striped bass, gilthead seabream, golden shiner (Notemigonus crysoleucas (Mitchill, 1814)), hardhead sea catfish (Aropius felis), squeteague (Cynoscion regalis (Bloch and Schneider, 1801)), and flathead grey mullet (Mugil cephalus Linnaeus, 1758), among others (Evans et al., 2002; Garcia, 2007). However, S. agalactiae may be a member of the normal bacterial flora for common carp (Cyprinus carpio Linnaeus, 1758) (Buller, 2014) and North African catfish (Clarias gariepinus (Burchell, 1822)) (O.L.M. Haenen, unpublished).

Mycobacterium marinum may cause chronic mild to severe disease in many freshwater and marine fish species, especially in warmwater (ornamental and edible) fish culture (DeCostere et al., 2004; Gauthier and Rhodes, 2009). Mycobacteriosis should be suspected when a typically chronic and progressive condition resulting in weight loss is seen. The external clinical signs in affected fish include scale loss and dermal ulceration, exophthalmos, abnormal behaviour, pigment changes, spinal defects, emaciation, and ascites (Gauthier and Rhodes, 2009). Some infected fish may develop fin and tail rot. Internal clinical signs of mycobacteriosis include enlargement of kidney, liver, and spleen, nodular skin lesions, abdominal distension, and haemorrhages (Chinabut, 1999). Some infected fish do not show clinical signs. Mycobacterium fortuitum and $M$. chelonae are also considered as causing fish tuberculosis in various species (Thoen and Schliesser, 1984; Stoskopf, 1993; Noga, 1995; Sanders and Swaim, 2001). Mycobacterium fortuitum is also considered a zoonotic pathogen (Nigrelli and Vogel, 1963).

\section{Diseases Common Zoonotic Bacteria May Cause in Predominantly Immuno- Compromised Humans}

Vibrio vulnificus may cause wound infections when a person with skin injury comes into contact with infected seawater, fish, or shellfish. This human skin infection may develop into fasciitis necroticans and, in exceptional cases, even full sepsis and death (Oliver, 2005; Ralph and Currie, 2007; Jones and Oliver, 2009; Austin, 2010). Immuno-compromised patients suffering from liver diseases are at risk. Mortality after wound infection may reach up to $25 \%$. After sepsis, mortality may reach up to $55 \%$, mostly within 48 hours of the first appearance of clinical signs (Haenen et al., 2013). Diagnostics, including ribotyping and genotyping of $V$. vulnificus can discriminate potential zoonotic strains from others (Arias et al., 1995, 1997; Rosche et al., 2005; Cohen et al., 2007; Sanjuán et al., 2009; Haenen et al., 2014).

Photobacterium damselae subsp. damselae may cause wound infections in humans (Dryden et al., 1989) and in exceptional cases necrotic fasciitis (Barber and Swygert, 2000), especially when humans are severely immunocompromised. An extreme variant of a highly severe necrotising fasciitis where antibiotic administration proved unable to control the progression of fatal infections was reported in some cases (Rivas et al., 2014). Few extremely serious infections with fatal outcome where patients infected by $P h$. damselae subsp. damselae developed multiple organ failure very soon after occurrence of initial symptoms despite therapy and surgical debarment of infected tissues were reported (Yamane et al., 1993)

Aeromonas hydrophila may cause local skin infections and occasionally, diarrheal disease (Lehane and Rawlin, 2000). Several large-scale retrospectives or prospective investigations on bacterial diarrhoea indicate that aeromonads are associated with stools of 0.5 to $16.9 \%$ of ill persons and 0 to $10 \%$ of controls (Janda and Abbot, 2010), but the role of A. hydrophila in causing diarrheal diseases is still debated.

Edwardsiella tarda may cause extra-intestinal infections through puncture wounds in adults with underlying disorders such as hepatobiliary disease, diabetes, malignancies, and other immunecompromising conditions (Lehane and Rawlin, 2000). It also causes gastrointestinal infections in children. Edwardsiella tarda is an important zoonotic pathogen, and is one of the principal causes of human infections acquired from fish, including from ornamental fish (Vandepitte et al., 1983; Javier, 2012; Haenen et al., 2013). Clinical disease in humans may include necrotic skin lesions, gastroenteritis, and in severe cases, septicaemia leading to osteomyelitis, meningitis, or cholecystitis (Gilman et al., 1971). At present, the zoonotic potential of E. anguillarum and E. piscicida is unknown.

As a consequence of fish handling, $S$. iniae may cause severe disease, including septicaemia, endocarditis, arthritis, meningitis, fever, and abdominal distension and pneumonia, especially in elderly humans with underlying conditions such as chronic rheumatic 
heart disease, osteoarthritis, duodenal ulcer, gallstones, diabetes mellitus, hepatitis, liver cirrhosis, alcoholism, hypertension, and hypothyroidism (Evans et al., 2009a). Soft-tissue infections and acute discitis have been reported by Fuller et al. (2001), and Koh et al. (2004). In humans, infection is clearly opportunistic, usually associated with direct infection of puncture wounds during the preparation of contaminated fish, and generally seen in immunocompromised individuals (Haenen et al., 2013). In 1995, an epidemic occurred in Toronto, Canada in patients handling live or freshly killed tilapia (Weinstein et al., 1997).

Streptococcus agalactiae may cause bacteraemia, septicaemia, meningitis, pneumonia, endophthalmitis (Chotmongkol et al., 2004), endocarditis (Kannan et al., 2001), spondylodiscitis (Sijpkens et al., 1997), and osteomyelitis (Bauer et al., 1997) in immunecompromised patients. In these cases, however, there were no links with fish as the source of infection. Infections in humans related to fish bacterial strains are scarce and were mostly opportunistic, associated with direct infection of puncture wounds during the preparation of contaminated fish, and generally in immunocompromised individuals (Haenen et al., 2013). The infection may be transmitted from a pregnant woman to her newborn child (Glaser et al., 2002). A link was proven between a fish strain and human neonatal meningitis infections in Japan (Evans et al., 2008, 2009b). Additionally, Liu et al. (2013) showed that a sequence type 7 (ST 7) strain from diseased cultured tilapia in the People's Republic of China showed a close genomic relationship with the human strain A909, although no related zoonosis was published. Verner-Jeffreys et al. (2012) isolated S. agalactiae from diseased warmwater red garra (Garra rufa (Heckel, 1843)) used for pedicure immediately after importation from Indonesia. This means that we need to be aware of the potential of $S$. agalactiae from fish to cause contact-zoonotic infections in humans.

Mycobacterium marinum may cause granulomatous inflammation and nodular or diffuse granulomas of the skin, subcutaneous tissues, and tendon sheaths of fingers and hands, and is referred to as "swimming pool granuloma", "fish tank granuloma", "fish handlers disease", "fish fanciers disease" or "fish TB" of man (Lawler, 1994; Lewis et al., 2003; Petrini, 2006; Haenen et al., 2013). Mycobacterium marinum and $M$. fortuitum are a potential occupational hazard for workers in the aquaculture and subtropical aquarium fish industries, as well as for private tropical pet fish owners who have direct contact with their fish when cleaning their aquaria. Piscine mycobacteria may cause morbidity and mortality in fish, but also have documented zoonotic potential for humans, especially for immunocompromised individuals. Occasionally, piscine mycobacteria can also spread to internal organs of the human body and have been isolated from pulmonary lesions, synovial fluid, and muscles (Blacklock and Dawson, 1979; Chinabut, 1999). Diagnosis in humans is set up by examining a biopsy of the suspected lesion. A history of any aquatic-related activities should be informed to the doctor. A Ziehl Neelsen stain of the biopsy is made and isolation should be done at $30^{\circ} \mathrm{C}$ (and not at $37^{\circ} \mathrm{C}$, as is often done at hospitals, because at this temperature no colonies of M. marinum will appear) (Haenen et al., 2013). For quick results, polymerase chain reaction (PCR) based techniques should be performed from the biopsy sample. Corticosteroids should never be given to patients infected with mycobacteriosis, as it is contraindicated. Precautionary principles such as education about the health risks, with hygiene and care to prevent contracting the disease must be applied to personnel involved in this industry and private aquarium owners, since mycobacteria may be serious zoonotic organisms. Mycobacterium fortuitum and M. chelonae may cause local skin infections, but also pulmonary inflammation (Tanaka et al., 1992).

In general, fish-related contact zoonoses are under reported, as in most countries they are non-notifiable (Haenen et al., 2013). In the United States of America, however, for instance, Mycobacterium marinum zoonosis is notifiable (Lahey, 2003), apart from Vibrio zoonosis (CDC, 2020).

\section{Conclusion}

Warmwater live fish culture, tropical fish, and their trade may pose a risk to professionals and fish hobbyists because of direct contact with potential contact-zoonotic bacteria in the infected fish or the transport water. Current border inspections for import control do not consider these risks, nor do import centres, or retail shops selling tropical fish. Awareness-raising about these risks among warmwater fish culturists, slaughter professionals, ornamental fish traders, warmwater fish hobbyists, veterinarians, medical practitioners, and governmental authorities is important.

To prevent contact zoonosis, good hygiene is a must. Hand and skin washing with soap after contact with warmwater fish and their holding water at fish farms, zoos, ornamental import sites, tropical aquaria, or warmwater fish processing facilities are a must. Regular screening for potential zoonotic bacteria in warmwater fish and their water is of utmost importance. Besides, monitoring of the health status of ornamental fish should be implemented on a global level, as its transboundary movement may act as a source of zoonotic infection and antimicrobial resistance for aquatic animals and humans.

\section{References}

Amal, M.N.A., Zamri-Saad, M. 2011. Streptococcosis in tilapia (Oreochromis niloticus): a review. Pertanika Journal of Tropical Agricultural Science 34:195-206. 
Arias C.R., Garay, E., Aznar, R. 1995. Nested PCR method for rapid and sensitive detection of Vibrio vulnificus in fish, sediments, and water. Applied and Environmental Microbiology 61:3476-3478. https://www.ncbi.nlm.nih.gov/pmc/articles/PMC167627/

Arias, C.R., Verdonck, L., Swings, J., Garay, E., Aznar, R. 1997. Intraspecific differentiation of Vibrio vulnificus biotypes by amplified fragment length polymorphism and ribotyping. Applied and Environmental Microbiology 63:2600-2606. https://www.ncbi.nlm .nih.gov/pmc/articles/PMC1389195/

Austin, B. 2010. Vibrios as causal agents of zoonoses. Veterinary Microbiology 140:310-317. https://doi.org/10.1016/j.vetmic.2009.03 $\underline{.015}$

Austin, B., Adams, C. 1996. Fish pathogens. In: The genus Aeromonas. Austin B., Altwegg M., Gosling P. J., Joseph S.W. (Eds.), J. Wiley \& Sons, Chichester, pp. 197-229.

Austin, B., Austin, D.A. 1999. Bacterial fish pathogens: disease in farmed and wild fish. Springer, New York, USA. $457 \mathrm{pp}$

Austin, B., Austin, D.A. 2007. Bacterial fish pathogens, disease of farmed and wild fish. $4^{\text {th }}$ Edition. Springer Praxis, Godalming, pp 2428, 81-98.

Barber, G.R., Swygert, J.S. 2000. Necrotizing fasciitis due to Photobacterium damsela in a man lashed by a stingray. New England Journal of Medicine 342:824.

Blacklock, Z.M., Dawson, D.J. 1979. Atypical mycobacteria causing nonpulmonary disease in Queensland. Pathology 11: 283-287.

Bowater, R.O., Forbes-Faulkner, J., Anderson, I.G., Condon, K. Robinson, B., Kong, F., Gilbert, G.L., Reynolds, A., Hyland, S., McPherson, G., Brien, J.O., Blyde, D. 2012. Natural outbreak of Streptococcus agalactiae (GBS) infection in wild giant Queensland grouper, Epinephelus lanceolatus (Bloch), and other wild fish in northern Queensland, Australia. Journal of Fish Diseases 35:173-186. https://doi.org/10.1111/j.1365-2761.2011.01332.x

Buller, N.B. 2014. Aquatic animal species and organism relationship. In: Bacteria and fungi from fish and other aquatic animals. A practical identification manual. $2^{\text {nd }}$ Edition. CABI, Wallingford, UK. pp. 418420.

Camus, A.C., Durborow, R.M., Hemstreet, W.G., Thune, R.L., Hawke, J.P. 1998. Aeromonas bacterial infections motile aeromonad septicemia. SRAC Publication No. 478, 4 pp. http://agrilife.org/fisheries2/files /2013/09/SRAC-Publication-No.-478-Aeromonas-BacterialInfections-Motile-Aeromonad-Septicemia.pdf

Castro, N., Toranzo, A.E., Barja, J.L., Núñez, S., Magariños B. 2006. Characterization of Edwardsiella tarda strains isolated from turbot, Psetta maxima (L.). Journal of Fish Diseases 29:541-547. https://doi.org/10.1111/j.1365-2761.2006.00750.x

CDC. 2020. Vibrio vulnificus \& wounds. Centers for Disease Control and Prevention, online. https://www.cdc.gov/vibrio/wounds.html (Accessed 01 July 2020).

Chanda, M., Paul, M., Maity, J., Dash, G., Gupta, S.S. 2011. The use of antibiotics and disinfectants in ornamental fish farms of West Bengal, India. Journal of Natural Science, Biology, and Medicine 2:139-140. https://doi.org/10.4103/0976-9668.92311

Chinabut, S. 1999. Mycobacteriosis and nocardiosis. In: Fish diseases and disorders, Vol. 3. Woo, P.T.K., Bruno, D.W. (Eds.), CABI Publishing, New York, pp. 319-340.

Chotmongkol, V., Soonfuang, W., Chaithawangul, S. 2004. Group B streptococcal meningitis and endopthalmitis. Journal of the Medical Association of Thailand 87:450-451.

Cohen, A.L., Oliver, J.D., DePaola, A., Feil, E.J., Boyd, E.F. 2007. Emergence of a virulent clade of Vibrio vulnificus and correlation with the presence of a 33-kilobase genomic island. Applied and
Environmental Microbiology 73:5553-5565. https://doi.org/10.1128 IAEM.00635-07

DeCostere, A., Hermans, K., Haesebrouck, F. 2004. Piscine mycobacteriosis: a literature review covering the agent and the disease it causes in fish and humans. Veterinary Microbiology 99:159-166. https://doi.org/10.1016/j.vetmic.2003.07.011

Delannoy, C.M.J., Crumlish, M., Fontaine, M., Pollock, J., Foster, G., Dagleish, M., Turnbull, J., Zadoks, R. 2013. Human Streptococcus agalactiae strains in aquatic mammals and fish. BMC Microbiology 13:41. https://doi.org/10.1186/1471-2180-13-41

Dryden, M., Legarde, M., Gottlieb, T., Brady, L., Ghosh, H.K. 1989. Vibrio damsela wound infections in Australia. Medical Journal of Australia 151:540-541. https://doi.org/10.5694/j.1326-5377.1989.tb128515.x

Eldar, A., Bejerano, Y., Livoff, A., Horovitcz, A., Bercovier, H. 1995. Experimental streptococcal meningo-encephalitis in cultured fish. Veterinary Microbiology 43:33-40. https://doi.org/10.1016/0378$\underline{1135(94) 00052-x}$

Evans, J.J., Bohnsack, J.F., Klesius, P.H., Whiting, A.A., Garcia, J.C. Shoemaker, C.A., Takahashi, S. 2008. Phylogenetic relationships among Streptococcus agalactiae isolated from piscine, dolphin, bovine and human sources: a dolphin and piscine lineage associated with a fish epidemic in Kuwait is also associated with human neonatal infections in Japan. Journal of Medical Microbiology 57:1369-1376. https://doi.org/10.1099/jmm.0.47815-0

Evans, J.J., Klesius, P.H., Gilbert, P.M., Shoemaker, C.A., Al Sarawi, M.A., Landsberg, J., Duremdez, R., Al Marzouk, A., Al Zenki, S. 2002. Characterization of $\beta$-haemolytic Group B Streptococcus agalactiae in cultured seabream, Sparus auratus L., and wild mullet, Liza klunzingeri (Day), in Kuwait. Journal of Fish Diseases 25: 505-513. https://doi.org/10.1046/j.1365-2761.2002.00392.x

Evans, J.J., Klesius, P.H., Haenen, O., Shoemaker, C.A. 2009a. Overview of zoonotic infections from fish and shellfish. Zoonotic infections from fish and shellfish. In Program, abstracts and report of European Association of Fish Pathologists (EAFP) workshop, pp. 6. Proceedings of the EAFP International Conference, 14-19 September 2009, Prague, Czech Republic.

Evans, J.J., Klesius, P.H., Pasnik, D.J., Bohnsack, J.F. 2009b. Human Streptococcus agalactiae isolate in Nile tilapia (Oreochromis niloticus). Emerging Infectious Diseases 15:774-776. https://doi.org /10.3201/eid1505.080222

FA0. 2018. FAO yearbook. Fishery and aquaculture statistics 2016. FAO, Rome. 108 pp. http://www.fao.org/fishery/static/Yearbook /YB2016_USBcard/booklet/web_i9942t.pdf

Fuller, J.D., Bast, D.J., Nizet, V., Low, D.E., Azavedo, J.C. 2001. Streptococcus iniae virulence is associated with a distinct genetic profile. Infection and Immunity 69:1994-2000. https://doi.org /10.1128/IAI.69.4.1994-2000.2001

Garcia, J.C. 2007. A comparative investigation of Streptococcus agalactiae isolates from fish and cattle. PhD Dissertation. Auburn University, Auburn, Alabama. 87 pp. http://www.ag.auburn.edu /fish/wp-content/uploads/formidable/GARCIA_JULIO_46.pdf

Gauthier, D.T., Rhodes, M.W. 2009. Mycobacteriosis in fishes: a review. Veterinary Journal 99:159-166. https://doi.org/10.1016 lj.tvjl.2008.05.012

Gilman, R.H., Madasamy, M., Gan, E., Mariappan, M., Davis, C.E., Kyser, K.A. 1971. Edwardsiella tarda in jungle diarrhoea and a possible association with Entamoeba histolytica. Southeast Asian Journal of Tropical Medicine and Public Health 2:186-189.

Glaser, P., Rusniok, C., Buchrieser, C., Chevalier, F., Frangeul, L., Msadek, T., Zouine, M., Couvé, E., Lalioui, L., Poyart, C., Trieu-Cuot, P., Kunst, F. 2002. Genome sequence of Streptococcus agalactiae, a 
pathogen causing invasive neonatal disease. Molecular Microbiology 45:1499-1513. https://doi.org/10.1046/j.1365-2958.2002.03126.x

Haenen, O.L.M., Evans, J.J., Berthe, F. 2013. Bacterial infections from aquatic species: potential for and prevention of contact zoonoses. Scientific and Technical Review of the Office International des Epizooties (Paris) 32:497-507. https://doi.org/10.20506 /rst.32.2.2245

Haenen, O.L.M., Van Zanten, E., Jansen, R., Roozenburg, I., Engelsma M.Y., Dijkstra, A., Boers, S.A., Voorbergen-Laarman, M., Möller, A.V.M. 2014. Vibrio vulnificus outbreaks in Dutch eel farms since 1996, strain diversity and impact. Diseases of Aquatic Organisms 108:201209. https://doi.org/10.3354/dao02703

Hawke, J.P. 2014. Photobacteriosis. In: American Fisheries SocietyFish Health Section Blue Book. 2014 Edition. Suggested procedures for the detection and identification of certain finfish and shellfish pathogens, Section 1. Diagnostic procedures for finfish and shellfish pathogens. http://www.afs-fhs.org/bluebook (Accessed 19 January 2018).

Hossain, M.J., Sun, D., McGarey, D.J., Wrenn, S., Alexander, L.M., Martino, M.E., Xing, Y., Terhune, J.S., Liles. M.R. 2014. An Asian origin of virulent Aeromonas hydrophila responsible for disease epidemics in United States-farmed catfish. mBio 5(e00848):14. https://doi.org /10.1128/mBio.00848-14

Janda, J.M., Abbot, S.L. 2010. The genus Aeromonas: taxonomy, pathogenicity and infection. Clinical Microbiology Reviews 23:35-73. https://doi.org/10.1128/CMR.00039-09

Javier, S. 2012. Edwardsiellosis, an emerging zoonosis of aquatic animals. Biohelikon: Immunity and Diseases 1:1-2. https://doi.org $\underline{\text { /10.5281/zenodo.816313 }}$

Jeffrey, S. Swygert, M.D. Bauer, T.M., Pippert, H., Zimmerli, W. 1997. Vertebral osteomyelitis caused by group B streptococci (Streptococcus agalactiae) secondary to urinary tract infection. European Journal of Clinical Microbiology and Infectious Diseases 16:244. https://doi.org/10.1007/BF01709590

Jones, M.K., Oliver, J.D. 2009. Vibrio vulnificus: disease and pathogenesis. Infection and Immunity 77:1723-1733. https://doi.org /10.1128/IAI.01046-08

Kannan, R., Komaranchath, A.M., Mathew, T., Ramprakash, B., Sundararaman, T., Sethuraman, K.R. 2001. Streptococcus agalactiae endocarditis. Journal of the Association of Physicians of India 49:1125-1126.

Kitao, T., Aoki, T., Sakoh, R. 1981. Epizootic caused by $\beta$-hemolytic Streptococcus species in cultured freshwater fish. Fish Pathology 15:301-307. https://www.jstage.jst.go.jp/article/jsfp1966/15/34/15_3-4_301/_pdf

Kodama, H., Murai, T., Nakanishi, Y., Yamamoto, F., Mikami, T., Izawa H. 1987. Bacterial infection which produces high mortality in cultured Japanese flounder (Paralichthys olivaceus) in Hokkaido. Japanese Journal of Veterinary Research 35:227-234. http://doi.org /10.14943/jjvr.35.4.227

Koh, T.H., Kurup, A., Chen, J. 2004. Streptococcus iniae discitis in Singapore. Emerging Infectious Diseases 10:1694-1695. https://doi.org/10.3201/eid1009.040029

Kusuda, R. 1992. Bacterial fish diseases in mariculture in Japan with special emphasis on streptococcosis. Israeli Journal of Aquaculture 44:140-140.

Labella, A., Berbel, C., Manchado, M., Castro, D., Borrego, J.J. 2011. Photobacterium damselae ssp. damselae an emerging pathogen affecting new cultured marine fish species in southern Spain. Chapter 9, In: Recent advances in fish farms. Aral, F., Doğu, Z. (Eds.), IntechOpen, Croatia, pp. 135-152.
Lahey, T. 2003. Invasive Mycobacterium marinum infections. Emerging Infectious Diseases 9:1496-1498. https://wwwnc.cdc.gov/eid /article/9/11/03-0192-t1

Lawler, A.R. 1994. Human Mycobacterium marinum Aronson infections. Journal of Aquaculture and Aquatic Sciences 6:93-94.

Lehane, L., Rawlin G.T. 2000. Topically acquired bacterial zoonoses from fish: a review. Medical Journal of Australia 173:256-259. https://doi.org/10.5694/j.1326-5377.2000.tb125632.x

Leotta, G.A., Piñeyro, P., Serena, S., Vigo, G.B. 2009. Prevalence of Edwardsiella tarda in Antarctic wildlife. Polar Biology 32:809-812. https://doi.org/10.1007/s00300-009-0610-9

Lewis, F.M., Marsh, B.J., Von Reyn, C.F. 2003. Fish tank exposure and cutaneous infections due to Mycobacterium marinum: tuberculin skin testing, treatment, and prevention. Clinical Infectious Diseases 37:390-397. https://doi.org/10.1086/376628

Liu, G., Zhang, W., Lu, C. 2013. Comparative genomics analysis of Streptococcus agalactiae reveals that isolates from cultured tilapia in China are closely related to the human strain A909. BMC Genomics 14:775. https://doi.org/10.1186/1471-2164-14-775

Meyer, F.P., Bullock, G.L. 1973. Edwardsiella tarda, a new pathogen of channel catfish (Ictalurus punctatus). Applied Microbiology 25:155156. https://www.ncbi.nlm.nih.gov/pmc/articles/PMC380755/

Miyazaki, T., Jo, Y., Kubota, S.S., Egusa, S. 1977. Histopathological studies on vibriosis of the Japanese eel Anguilla japonica. Part 1. Natural infection. Fish Pathology 12:163-170. https://doi.org/10.3147 /jsfp. 12.163

Mohanty, B.R., Sahoo, P.K. 2007. Edwardsiellosis in fish: a brief review. Journal of Bioscience 32:1331-1344. https://doi.org/10.1007/s12038007-0143-8

Nigrelli, R.F., Vogel, H. 1963. Spontaneous tuberculosis in fishes and other cold-blooded vertebrates with special reference to Mycobacterium fortuitum Cruz from fish and human lesions. Zoologica 48:131-144. https://biostor.org/reference/194049

Noga, E.J. 1995. Fish disease. Diagnosis and treatment. $1^{\text {st }}$ Edition. lowa State University Press, Ames, USA. 367 pp.

OFI (Ornamental Fish International). 2018. Ornamental fish industry data. $\quad$ https://www.ofish.org/ornamental-fish-industry-data (Accessed 6 November 2018).

Oliver, J.D. 2005. Wound infections caused by Vibrio vulnificus and other marine bacteria. Epidemiology \& Infection 133:383-391. https://doi.org/10.1017/s0950268805003894

Perera, R., Johnson, S., Collins, M., Lewis, D.H. 1994. Streptococcus iniae associated with mortality of Tilapia nilotica and $T$. aurea hybrids. Journal of Aquatic Animal Health 6:335-340. https://doi.org /10.1577/1548-8667(1994)006\%3C0335:SIAWMO\%3E2.3.C0;2

Petrini, B. 2006. Mycobacterium marinum: ubiquitous agent of waterborne granulomatous skin infections. European Journal of Clinical Microbiology and Infectious Diseases 25:609-613. https://doi.org/10.1007/s10096-006-0201-4

Plumb, J.A. 1999. Eel bacterial diseases. In: Health maintenance and principal microbial diseases of cultured fishes. lowa State University Press, Ames, USA, pp. 327-344.

Ralph, A., Currie, B.J. 2007. Vibrio vulnificus and V. parahaemolyticus necrotising fasciitis in fishermen visiting an estuarine tropica northern Australian location. Journal of Infection 54:e111-e114. https://doi.org/10.1016/j.jinf.2006.06.015

Rivas, A.J., Lemos, M.L., Osorio, C.R. 2013. Photobacterium damselae subsp. damselae, a bacterium pathogenic for marine animals and humans. Frontiers in Microbiology 4:283. https://dx.doi.org /10.3389\%2Ffmicb.2013.00283

Rivas, A.J., Lemos, M.L., Osorio, C.R. 2013. Photobacteriusm damselae subsp. damselae, a bacterium pathogenic for marine animals and 
humans. Frontiers in Microbiology 4:283 https://doi.org/10.3389/fmicb.2013.00283

Romalde, J.L. 2002. Photobacterium damselae subsp. piscicida: an integrated view of a bacterial fish pathogen. International Microbiology 5:3-9. https://doi.org/10.1007/s10123-002-0051-6

Rosche, T.M., Yano, Y., Oliver, J.D. 2005. A rapid and simple PCR analysis indicates there are two subgroups of Vibrio vulnificus which correlate with clinical or environmental isolation. Microbiology and Immunology 49:381-389. https://doi.org/10.1111/j.13480421.2005.tb03731.x

Sakata, T., Hattori, M. 1988. Characteristics of Vibrio vulnificus isolated from diseased tilapia. Fish Pathology 23:33-40. https://www.jstage .jst.go.jp/article/jsfp1966/23/1/23_1_33/_pdf

Salati, F. 2011. Enterococcus seriolicida and Streptococcus spp. (S. iniae, S. agalactiae and $S$. dysgalactiae) In: Fish diseases and disorders, viral, bacterial and fungal infections, Vol. 3, $2^{\text {nd }}$ Edition. Woo P.T.K., Bruno D.W. (Eds.), CABI, Wallingford, UK, pp. 375-396.

Sanders, G.E., Swaim, L.E. 2001. Atypical piscine mycobacteriosis in Japanese medaka (Oryzias latipes). Comparative Medicine 51:171-175. https://www.ingentaconnect.com/content/aalas/cm/2001/0000005 $\underline{1 / 00000002 / a r t 00012}$

Sanjuán, E., Fouz, B., Oliver, J., Amaro, C. 2009. Evaluation of genotypic and phenotypic methods to distinguish clinical from environmental Vibrio vulnificus strains. Applied and Environmental Microbiology 75:1604-1613. https://doi.org/10.1128/AEM.01594-08

Sharma, V.K., Kaura, Y.K., Singh, I.P. 1974. Frogs as carriers of Salmonella and Edwardsiella. Antonie Van Leeuwenhoek 40:171-175. https://doi.org/10.1007/bf00394564

Sijpkens, Y.W.J., Van't Wout, J.W., Breedveld, F.C. 1997. Spondylodiscitis door. Streptococcus agalactiae. Nederlands Tijdschrift voor Geneeskunde 141:534-536.

Soltani, M., Jamshidi, S., Sharifpour, I. 2005. Streptococcosis caused by Streptococcus iniae in farmed rainbow trout (Oncorhynchus mykiss) in Iran: biophysical characteristics and pathogenesis. Bulletin of the European Association of Fish Pathologists 25:95-106. https://pdfs.semanticscholar.org/c088/039e4230d778fa97a358dc2 d2e3ebc083314.pdf

Stoskopf, M.K. 1993. Fish medicine. W.B. Saunders Company, Philadelphia. 882 pp.

Tan, R.J., Lim, E.W. 1977. Occurrence of Edwardsiella tarda in the household lizard, Gecko gecko. Japanese Journal of Medical Science and Biology 30:321-323.

Tanaka, H., Kurihara, M., Takahashi, K., Honda, Y., Asakawa, M., Oshima, S. 1992. Mycobacterium fortuitum pulmonary infection in a healthy $17-$ year-old man. Kekkaku 67:613-619.

Thoen, C.O., Schliesser, T.A. 1984. Mycobacterial infections in coldblooded animals. In: The Mycobacteria, Part B, $1^{\text {st }}$ Edition, Kubica G.P., Wayne L.G. (Eds.), Marcel Dekker, Inc., New York, N.Y., pp. 12971311.

Vandepitte, J., Lemmens P., De Swert, L. 1983. Human edwardsiellosis traced to ornamental fish. Journal of Clinical Microbiology 17:165167. https://www.ncbi.nlm.nih.gov/pmc/articles/PMC272596/

Verner-Jeffreys, D.W., Baker-Austin, C., Pond, M.J., Rimmer, G.S., Kerr, R., Stone, D., Griffin, R., White, P., Stinton, N., Denham, K., Leigh, J., Jones, N., Longshaw, M., Feist, S.W. 2012. Zoonotic disease pathogens in fish used for pedicure. Emerging Infectious Diseases 18:1006-1008. https://doi.org/10.3201/eid1806.111782

Wang, X., Yan, M., Wang, O., Ding, L., Li, F. 2012. Identification of Edwardsiella tarda isolated from duck and virulence genes detection. African Journal of Microbiological Researches 6:4970-4975. https://doi.org/10.5897/AJMR11.1604
Weinstein, M.R., Low, D.E., McGeer, A., Litt, M. 1997. Invasive infections due to a fish pathogen, Streptococcus iniae. New England Journal of Medicine 337:589-594. https://www.nejm.org/doi/full/10.1056 /NEJM199708283370902

Weir, M., Rajić, A., Dutil, L., Cernicchiaro, N., Uhland, C., Mercier, B., Tuševljak, N. 2011. Zoonotic bacteria, antimicrobial use and antimicrobial resistance in ornamental fish: a systematic review of the existing research and survey of aquaculture-allied professionals. Epidemiology and Infection 140:192-206.

Xu, T., Zhang, X.H. 2014. Edwardsiella tarda: An intriguing problem in aquaculture. Aquaculture 431:129135. https://doi.org/10.1016 /j.aquaculture.2013.12.001

Yamane, K., Asato, J., Kawade, N., Takahashi, H., Kimura, B., Arakawa, Y. 2004. Two cases of fatal necrotizing fasciitis caused by Photobacteriusm damselae subsp. damselae in Japan. Journal of Clinical Microbiology 42:1370-1372. https://doi.org/10.1128 IJCM.42.3.1370-1372 